\title{
THE DAY OF JUDGEMENT - EPILOGUE
}

The story of Sally Robinson, candidate, continued.

A year later, Sally got exactly the job she wanted. By that time, she had gained confidence at interviews, although it took several more failures before she really managed to do so. She now has a clear idea of what they are all about, she knows how she can best put herself across, she prepares well, and she gets there in plenty of time. 'They are a challenge, but they do not scare me any longer,' she says, 'I know what I have to do and say.'

On the occasion that she was successful, Sally was surprised to find Shirley Garnett interviewing her again. This time, however, Shirley was no longer hesitant and unprepared - she was firmly in control, asked good questions, and made Sally feel at ease. But then, Sally was that much easier to interview the second time.

Shirley had moved on from her previous post. It was her experience as a candidate for her new post that made her think a lot about what was really involved in interviewing. When, recently, she had to select her new team, she studied everything she could find about recruitment and selection. She went on courses, looked at herself on video and got people who were better than her to give her comments on her style. Now she has picked the people, she is quietly checking whether the predictions she made about each of them were correct. She has kept her rating sheets and records of interviews for this purpose.

Miss Williams has not done anything to change her interviewing ideas, or her ideas on anything else, for that matter. However, she has made one major change in her life - she has retired from the service. 